\title{
Hypothesis Testing for the Questionnaire Investigation on the Needs at Fuji City
}

\author{
Yuki Higuchi ${ }^{1}$, Akane Okubo $^{2}$, Daisuke Suzuki ${ }^{3} \&$ Kazuhiro Takeyasu ${ }^{4}$ \\ ${ }^{1}$ Faculty of Business Administration, Setsunan University, Japan \\ ${ }^{2}$ NIHON University Junior College, Japan \\ ${ }^{3}$ Fujisan Area Management Company, Japan \\ ${ }^{4}$ College of Business Administration, Tokoha University, Japan \\ Correspondence: Yuki Higuchi, Faculty of Business Administration, Setsunan University, Japan.
}

\author{
Received: April 17, 2018 \\ doi:10.5539/ibr.v11n6p139 \\ Accepted: May 9, $2018 \quad$ Online Published: May 18, 2018 \\ URL: https://doi.org/10.5539/ibr.v11n6p139
}

\begin{abstract}
Shopping streets at local city in Japan became old and are generally declining. In this paper, we handle the area rebirth and/or regional revitalization of shopping street. We focus on Fuji city in Japan. Four big festivals are held at Fuji city. Many people visit these festivals including residents in that area. Therefore a questionnaire investigation to the residents and visitors is conducted during these periods in order to clarify residents and visitors' needs for the shopping street and utilize them to the plan building of the area rebirth and/or regional revitalization of shopping street. Hypothesis testing was executed based on that. We have set 9 Null hypotheses. In the hypothesis testing, 4 cases out of 9 null hypotheses were rejected and nearly half of hypotheses were insisted clearly. We have obtained fruitful results. To confirm the findings by utilizing the new consecutive visiting records would be the future works to be investigated.
\end{abstract}

Keywords: Fuji city, area rebirth, regional vitalization, festival, hypothesis testing

\section{Introduction}

Shopping streets at local city in Japan are generally declining. It is because most of them were built in the so-called "High Growth Period (1954-1973)". Therefore they became old and area rebirth and/or regional revitalization are required everywhere.

There are many papers published concerning area rebirth or regional revitalization. Inoue (2017) has pointed out the importance of tourism promotion. Ingu et al. (2017) made a study on the application of geothermal power generation to local revitalization in Obama Town. Kotani (2017) developed the project of shutter art to Wakkanai Chuo shopping street in Hokkaido/Japan. Ohkubo (2017) has made a questionnaire research at Jigenji shopping street in Kagoshima Prefecture/Japan and analyzed the current condition and future issues. For about tourism, many papers are presented from many aspects as follows.

Yoshida et al. designed and conducted a visitor survey on the spot which used a questionnaire to investigate the activities of visitors to the Ueno district in Taito ward/Tokyo. Doi et al. analyzed the image of the Izu Peninsula as a tourist destination in their 2003 study "Questionnaire Survey on the Izu Peninsula." Kano conducted tourist behavior studies in Atami city in 2008, 2009, 2014 and in other years.

In this paper, we handle the area rebirth and/or regional revitalization of shopping street. We focus on Fuji city in Japan. Fuji city is located in Shizuoka Prefecture. Mt. Fuji is very famous all around the world and we can see its beautiful scenery from Fuji city which is located at the foot of Mt. Fuji. There are two big shopping street in Fuji city. One is Yoshiwara shopping street and another one is Fuji shopping street. They became old and building area rebirth and regional revitalization plan have started. Following investigation was conducted by the joint research group (Fuji Chamber of Commerce \& Industry, Fujisan Area Management Company, Katsumata Maruyama Architects, Kougakuin University and Tokoha University). The main project activities are as follows.

A Investigation on the assets which are not in active use

B Questionnaire Investigation to Entrepreneur 


\section{Questionnaire Investigation to the residents and visitors}

After that, area rebirth and regional revitalization plan were built.

In this paper, we handle above stated C. Four big festivals are held at Fuji city. Two big festivals are held at Yoshiwara district(Yoshiwara shopping street) and two big festivals at Fuji district(Fuji shopping street). At Yoshiwara district, Yoshiwara Gion Festival is carried out during June and Yoshiwara Shukuba (post-town) Festival is held during October. On the other hand, Kinoene Summer Festival is conducted during August and Kinoene Autumn Festival is performed during October at Fuji district. Many people visit these festivals including residents in that area.

Therefore questionnaire investigation of $\mathrm{C}$ is conducted during these periods. Finally, we have obtained 982 sheets (Yoshiwara district: 448, Fuji district: 534). Basic statistical analysis and Hypothesis testing analysis are executed based on that.

In this paper, a questionnaire investigation is executed in order to clarify residents and visitors' needs for the shopping street and utilize them to the plan building of the area rebirth and/or regional revitalization of shopping street. Hypothesis testing was executed based on that. We have set 9 Null hypotheses. Some interesting and instructive results are obtained.

The rest of the paper is organized as follows. Outline of questionnaire investigation is stated in section 2. In section 3, Hypothesis testing is executed which is followed by the Remarks is stated in section 4.

\section{Outline and the Basic Statistical Results of the Questionnaire Research}

\subsection{Outline of the Questionnaire Research}

A questionnaire investigation to the residents and visitors is conducted during these periods in order to clarify residents and visitors' needs for the shopping street, and utilize them to the plan building of the area rebirth and/or regional revitalization of shopping street. The outline of questionnaire research is as follows. Questionnaire sheet is attached in Appendix.

1) Scope of investigation: Residents and visitors who have visited four big festivals at Fuji city in Shizuoka Prefecture, Japan

2) Period: Yoshiwara Gion Festival: June 11,12/2016 Yoshiwara Shukuba (post-town) Festival: October 9/2016 Kinoene Summer Festival: August 6,7/2016 Kinoene Autumn Festival: October 15,16/2016

3) Method: Local site, Dispatch sheet, Self-writing

4) Collection: Number of distribution 1400, Number of collection 982(collection rate 70.1\%), Valid answer 982

\subsection{Basic Statistical Results}

Now, we show the main summary results by single variable.

\subsubsection{Characteristics of Answers}

(1) Sex (Q7)

Male $48.9 \%$, Female $51.1 \%$

These are exhibited in Figure 1.

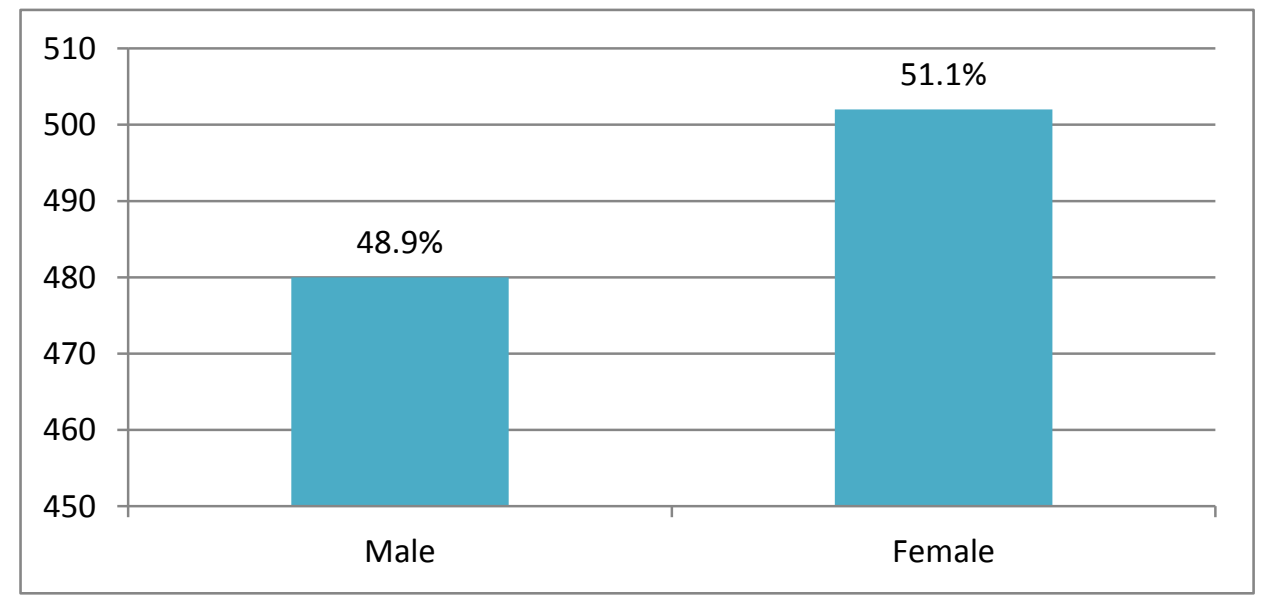

Figure 1. Sex (Q7) 
(2) Age (Q8)

$10^{\text {th }} 16.2 \%, 20^{\text {th }} 14.8 \%, 30^{\text {th }} 22.4 \%, 40^{\text {th }} 17.4 \%, 50^{\text {th }} 11.6 \%, 60^{\text {th }} 10.5 \%$, More than $707.1 \%$

These are exhibited in Figure 2.

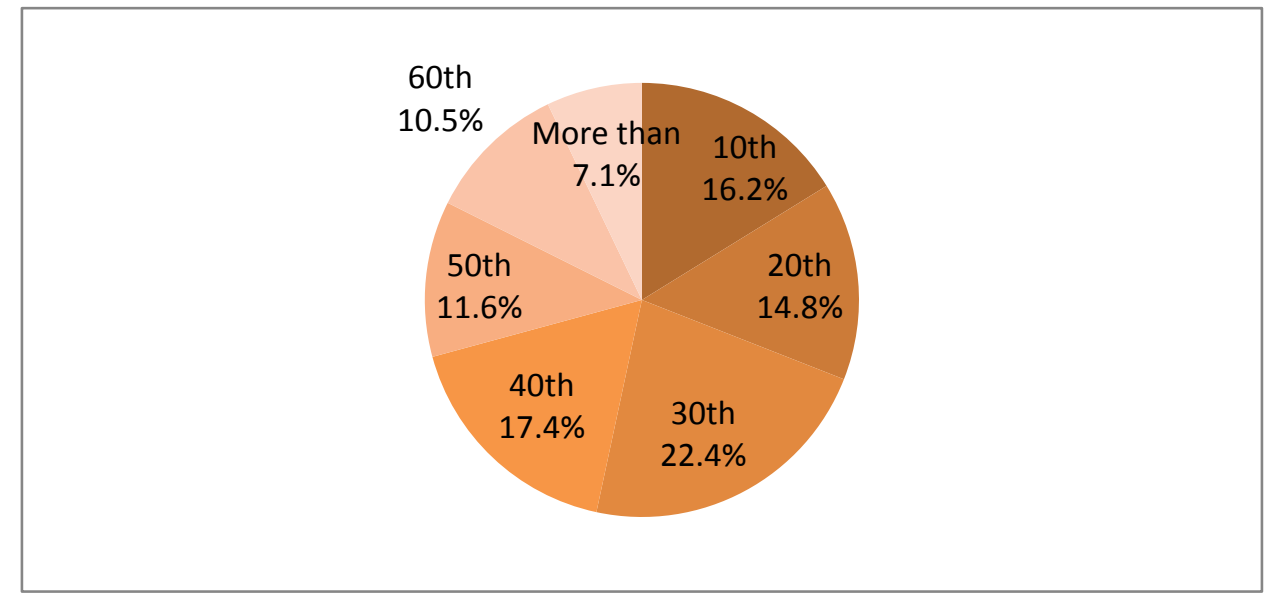

Figure 2. Age (Q8)

(3) Residence (Q9)

a. Fuji city $56.4 \%$, b. Fujinomiya city $18.0 \%$, c. Numazu city $7.2 \%$, d. Mishima city $2.3 \%$, e. Shizuoka city $4.2 \%$, F. Else (in Shizuoka Prefecture) 5.1\%, g. Outside of Shizuoka Prefecture 6.9\%

These are exhibited in Figure 3.

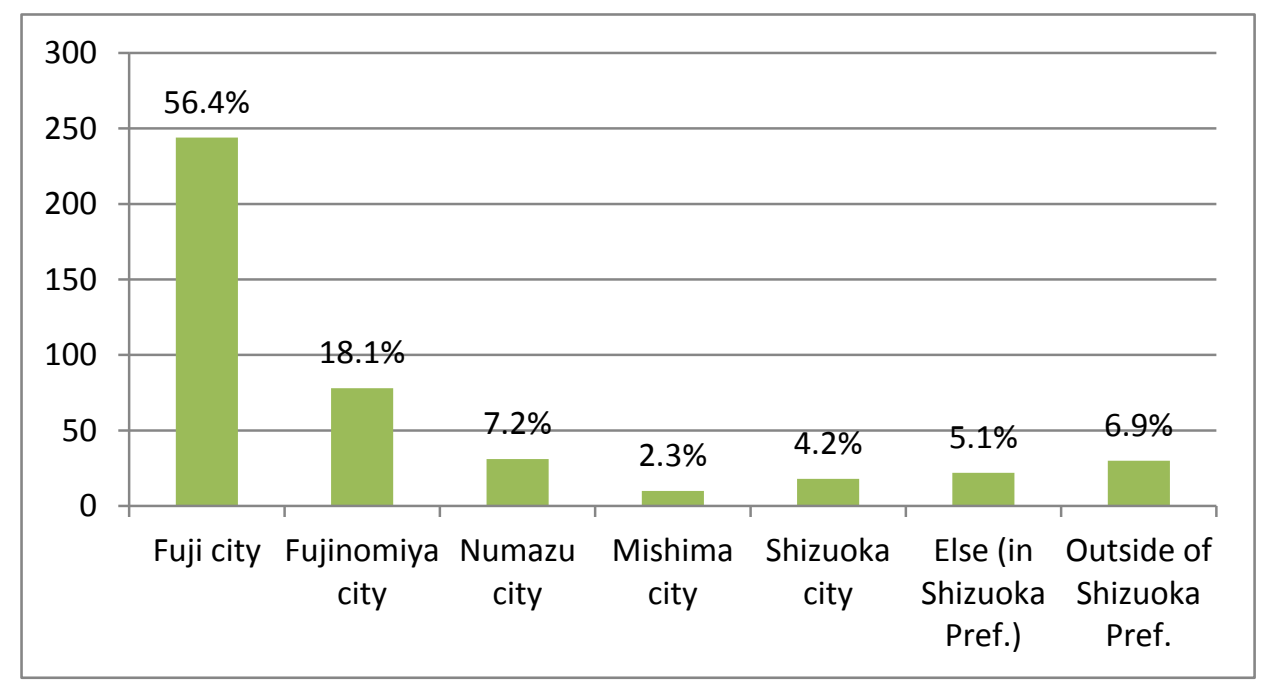

Figure 3. Residence (Q9)

2.1.2 Summary Results for the Items Used in Hypothesis Testing

(1) How often do you come to this shopping street? (Q1)

Everyday $17.4 \%$, More than 1 time a week $16.5 \%$, More than 1 time a month $25.8 \%$, More than 1 time a year $31.6 \%$, First time $4 \%$, Not filled in $4.8 \%$

These are exhibited in Figure 4. 


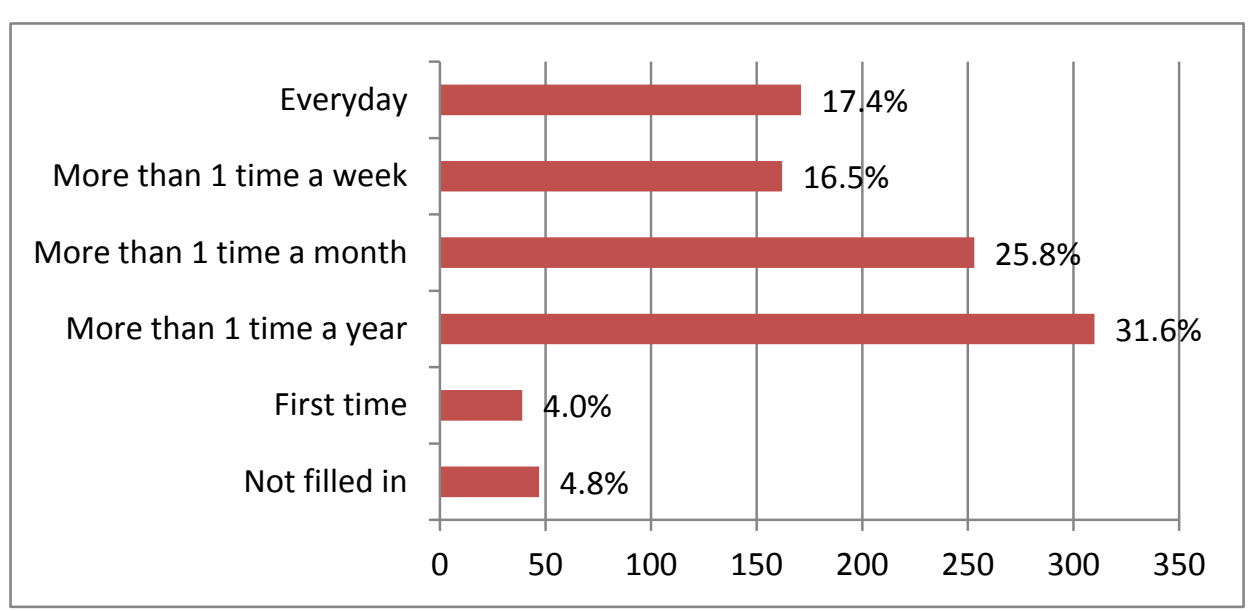

Figure 4. How often do you come to this shopping street? (Q1)

(2) What is the purpose of visiting here? (Q2)

Shopping $18.8 \%$, Eating and drinking $13.4 \%$, Business $7.4 \%$, Celebration, event $40.2 \%$, Leisure, amusement $4.0 \%$, miscellaneous $16.1 \%$

These are exhibited in Figure 5.

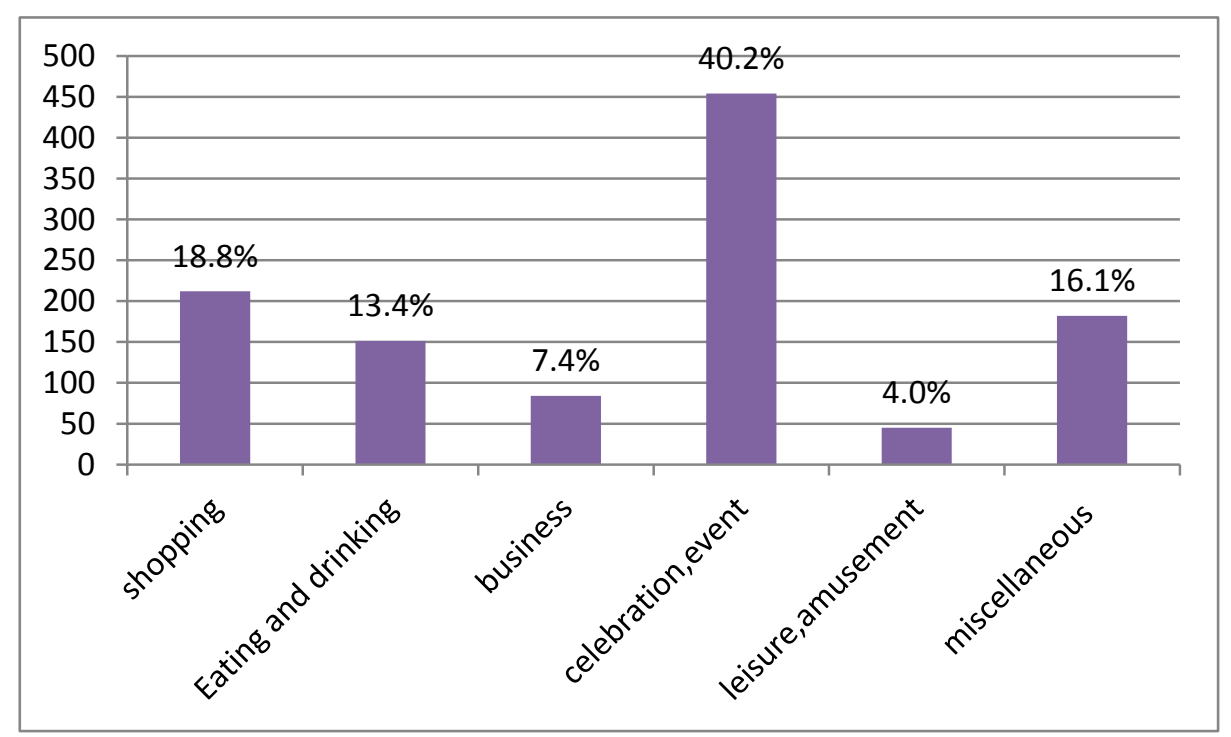

Figure 5. What is the purpose of visiting here? (Q2)

(3) How do you feel about the image of the surrounding area at this shopping street? (Q3)

Beautiful $51.5 \%$, Ugly $48.5 \%$, Of the united feeling there is $45.6 \%$, Scattered $54.4 \%$, Varied $39.2 \%$, Featureless $60.8 \%$, New 32.4\%, Historic 67.6\%, Full of nature 54.5\%, Urban 45.5\%, Cheerful 46.5\%, Gloomy 53.5\%, Individualistic $44.0 \%$, Conventional $56.0 \%$, Friendly 59.5\%, Unfriendly $40.5 \%$, Healed $53.7 \%$, Stimulated 46.3\%, Open 46.2\%, exclusive 53.8\%, Want to reside 44.3\%, Do not want to reside 55.7\%, Warm 58.5\%, Aloof $41.5 \%$, Fascinating $45.5 \%$, Not fascinating $54.5 \%$, Want to play $47.4 \%$, Want to examine deliberately $52.6 \%$, Lively $38.4 \%$, Calm $61.6 \%$, Atmosphere of urban $29.1 \%$, Atmosphere of rural area $70.9 \%$

These are exhibited in Figure 6. 


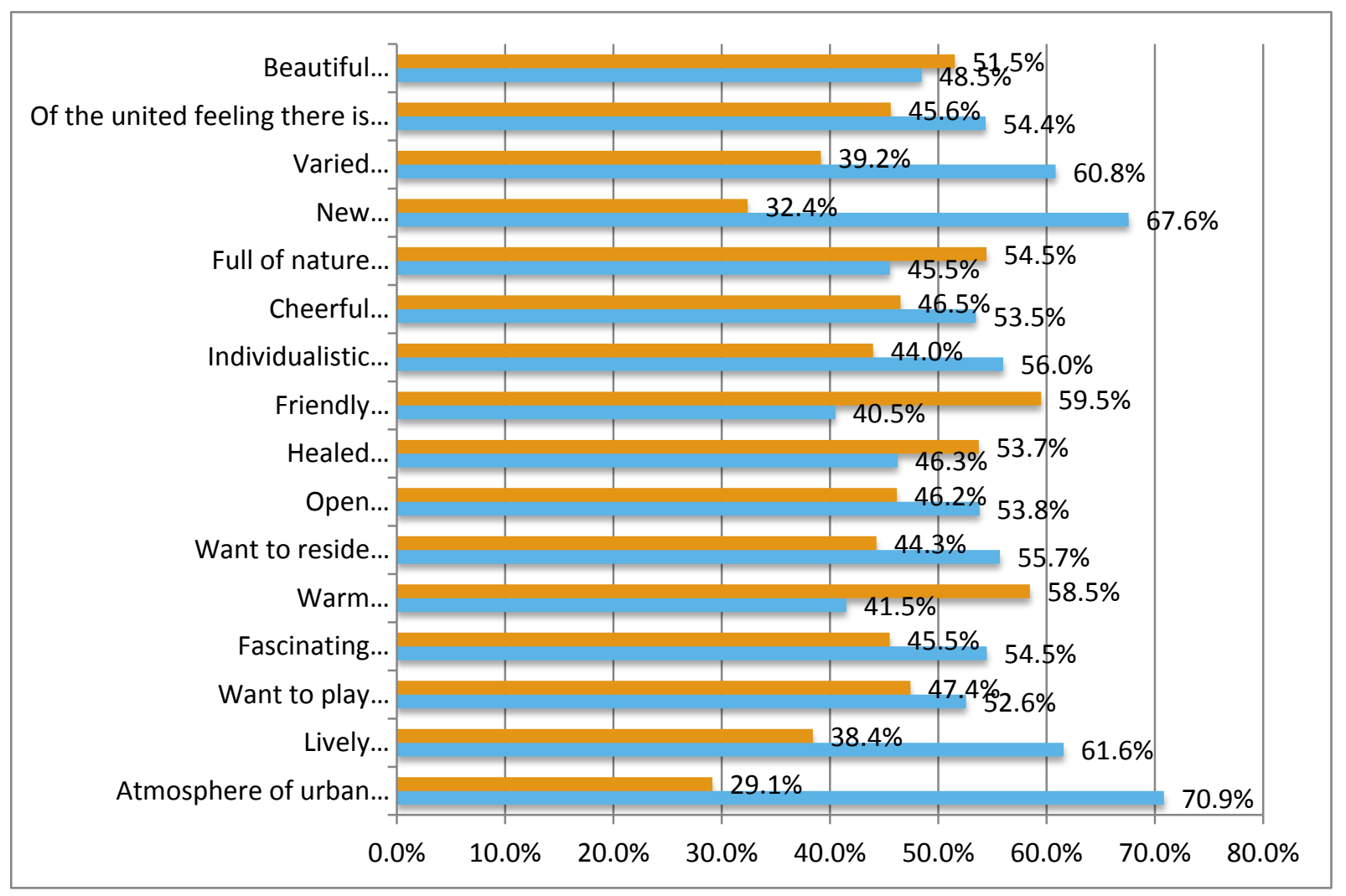

Figure 6. How do you feel about the image of the surrounding area at this shopping street? (Q3)

(4) There are many old building at the age of nearly 50 years. Do you think we can still use them? (Q4)

(We explain it a little more bit. As there often arises earthquake in Japan, many buildings are re-built after 50 years they have been built. But some of them can still be useful with some repairs. That is why this question is executed.)

Can use it $44.1 \%$, Cannot use it $31.4 \%$, Have no idea $24.5 \%$

These are exhibited in Figure 7.

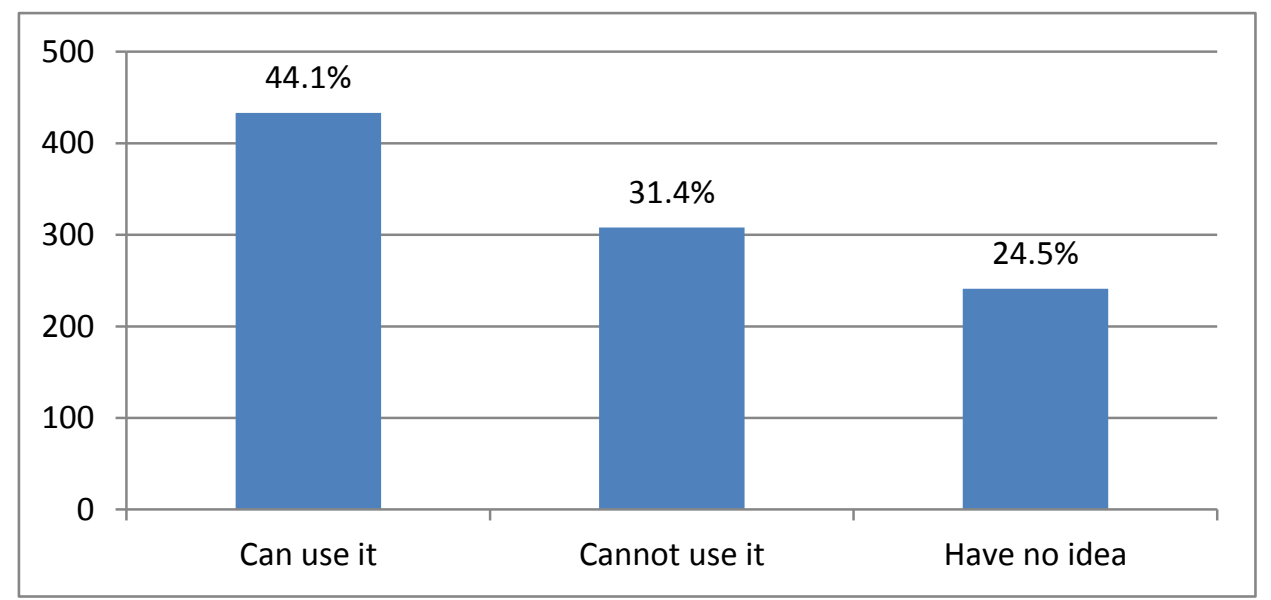

Figure 7. There are many old building at the age of nearly 50 years. Do you think we can still use them? (Q4)

\section{Hypothesis Testing}

Hereinafter we make hypothesis testing based upon the questionnaire investigation data.

\subsection{Setting Hypothesis}

We set the following 9 themes before setting Null Hypothesis.

A-1) Those who come frequently (every day) think that old buildings cannot be used. 
A-2) Those who do not come so often (once a year) think that old buildings cannot be used.

A-3) Those who are at the age of less than 40 think that old buildings can be used.

A-4) Men think that old buildings cannot be used.

A-5) Those who answered that old buildings can be used think that they want to reside.

A-6) Those who answered that the image of the street is lively think that they want to reside.

A-7) Those who came from far away (Miscellaneous in Shizuoka Prefecture, Outside of Shizuoka Prefecture) think that they cannot judge whether old buildings can be used or not.

A-8) Those who answered that the purpose of visiting the shopping street is eating and drinking are male in majority.

A-9) Those who live in Fuji city have the purpose of eating and drinking while visiting the shopping street.

Now, we set the following 9 Null hypotheses.

B-1) There is not so much difference whether "those who come frequently (every day) think that old buildings cannot be used" or not.

B-2) There is not so much difference whether "those who do not come so often (once a year) think that old buildings cannot be used" or not.

B-3) There is not so much difference whether "those who are at the age of less than 40 think that old buildings can be used" or not.

B-4) There is not so much difference whether "men think that old buildings cannot be used" or not.

B-5) There is not so much difference whether "those who answered that old buildings can be used think that they want to reside" or not.

B-6) There is not so much difference whether "those who answered that the image of the street is lively think that they want to reside" or not.

B-7) There is not so much difference whether "those who came from far away ( Miscellaneous in Shizuoka Prefecture, Outside of Shizuoka Prefecture) think that they cannot judge whether old buildings can be used or not" or not.

B-8) There is not so much difference whether "t hose who answered that the purpose of visiting the shopping street is eating and drinking are male in majority" or not.

B-9) There is not so much difference whether "those who live in Fuji city have the purpose of eating and drinking while visiting the shopping street" or not.

\subsection{Hypothesis Testing}

$x^{2}$ hypothesis testing is executed in order to clarify tourists' behavior. $x^{2}$ hypothesis testing is to clarify the difference between the expected value and the observed data, which is shown in Eq.(1).

$x^{2}=\sum_{i=1}^{n} \frac{\left(O_{i}-E_{i}\right)^{2}}{E_{i}}$

Where $O_{i}$ is an observed data and $E_{i}$ is an expected value. The results of statistical hypothesis testing are as follows.

Null Hypothesis B-1) There is not so much difference whether "those who come frequently (every day) think that old buildings cannot be used" or not.

Summary table concerning Null Hypothesis B-1) is exhibited in Table 1.

Table 1. Summary table for Null Hypothesis B-1)

Q1: How often do you come to this shopping street? : Everyday

Q4: There are many old building at the age of nearly 50 years. Do you think we can still use them? 


\begin{tabular}{|c|c|c|c|c|}
\hline \multirow[b]{2}{*}{ Q1 } & \multicolumn{4}{|c|}{$\mathrm{Q} 4$} \\
\hline & & Can use it & $\begin{array}{l}\text { Cannot use it / } \\
\text { Have no idea }\end{array}$ & Total \\
\hline \multirow{2}{*}{ Everyday } & Frequency & 79 & 92 & 171 \\
\hline & $\%$ & 46.20 & 53.80 & 100.00 \\
\hline \multirow{2}{*}{ Less than that } & Frequency & 332 & 432 & 764 \\
\hline & $\%$ & 43.46 & 56.54 & 100.00 \\
\hline \multirow{2}{*}{ Total } & Frequency & 411 & 524 & 935 \\
\hline & $\%$ & 43.96 & 56.04 & 100.00 \\
\hline
\end{tabular}

The null hypothesis is not rejected. It can be said that there is not so much difference whether "those who come frequently (every day) think that old buildings cannot be used" or not.

Null Hypothesis B-2): There is not so much difference whether "those who do not come so often (once a year) think that old buildings cannot be used" or not.

Summary table concerning Null Hypothesis B-2) is exhibited in Table 2.

Table 2. Summary table for Null Hypothesis B-2)

Q1: How often do you come to this shopping street? : 1 time a year

Q4: There are many old building at the age of nearly 50 years. Do you think we can still use them?

\begin{tabular}{|c|c|c|c|c|}
\hline \multicolumn{5}{|c|}{ Q4 } \\
\hline Q1 & & Can use it & $\begin{array}{l}\text { Cannot use it / } \\
\text { Have no idea }\end{array}$ & Total \\
\hline \multirow{2}{*}{1 time a year } & Frequency & 130 & 180 & 310 \\
\hline & $\%$ & 41.94 & 58.06 & 100.00 \\
\hline \multirow{2}{*}{ More than that } & Frequency & 281 & 344 & 625 \\
\hline & $\%$ & 44.96 & 55.04 & 100.00 \\
\hline \multirow{2}{*}{ Total } & Frequency & 411 & 524 & 935 \\
\hline & $\%$ & 43.96 & 56.04 & 100.00 \\
\hline
\end{tabular}

The null hypothesis is not rejected. It can be said that there is not so much difference whether "those who do not come so often (once a year) think that old buildings cannot be used" or not.

Null Hypothesis B-3) There is not so much difference whether "those who are at the age of less than 40 think that old buildings can be used" or not.

Summary table concerning Null Hypothesis B-3) is exhibited in Table 3.

Table 3. Summary table for Null Hypothesis B-3)

Q8: Age

Q4: There are many old building at the age of nearly 50 years. Do you think we can still use them?

\begin{tabular}{ccrrr}
\hline \multirow{2}{*}{ Q8 } & \multicolumn{5}{c}{ Q4 } \\
Cannot use it / \\
Can use it & Have no idea & Total \\
\hline \multirow{2}{*}{ Less than 40th } & Frequency & 309 & 386 & 695 \\
& $\%$ & 44.46 & 55.54 & 100.00 \\
\hline \multirow{2}{*}{ More than 50th } & Frequency & 124 & 163 & 287 \\
& $\%$ & 43.21 & 56.79 & 100.00 \\
\hline \multirow{2}{*}{ Total } & Frequency & 433 & 549 & 982 \\
& $\%$ & 44.09 & 55.91 & 100.00 \\
\hline & & & significance probability & 0.719
\end{tabular}


The null hypothesis is not rejected. It can be said that there is not so much difference whether "those who are at the age of less than 40 think that old buildings can be used" or not.

Null Hypothesis B-4) There is not so much difference whether "men think that old buildings cannot be used" or not.

Summary table concerning Null Hypothesis B-4) is exhibited in Table 4.

Table 4. Summary table for Null Hypothesis B-4)

Q7: Sex

Q4: There are many old building at the age of nearly 50 years. Do you think we can still use them?

\begin{tabular}{ccrrrr}
\hline \multirow{2}{*}{ Q7 } & & \multicolumn{2}{c}{ Q4 } & & \multicolumn{2}{c}{ Total } \\
\hline \multirow{2}{*}{ Male } & Frequency & 212 & 168 & 100 & 480 \\
& $\%$ & 44.17 & 35.00 & 20.83 & 100.00 \\
\hline \multirow{2}{*}{ Female } & Frequency & 221 & 140 & 141 & 502 \\
& $\%$ & 44.02 & 27.89 & 28.09 & 100.00 \\
\hline \multirow{2}{*}{ Total } & Frequency & 433 & 308 & 241 & 982 \\
& $\%$ & 44.09 & 31.36 & 24.54 & 100.00 \\
\hline & & & & significance probability & 0.010
\end{tabular}

The null hypothesis is rejected with $1 \%$ significance level. It can be said that men think that old buildings cannot be used.

Null Hypothesis B-5) There is not so much difference whether "those who answered that old buildings can be used think that they want to reside" or not.

Summary table concerning Null Hypothesis B-5) is exhibited in Table 5.

Table 5. Summary table for Null Hypothesis B-5)

Q4: There are many old building at the age of nearly 50 years. Do you think we can still use them?

Q3: How do you feel about the image of the surrounding area at this shopping street? : Want to reside

\begin{tabular}{ccrrr}
\hline \multicolumn{5}{c}{ Q3: Want to reside } \\
Q4 & \multicolumn{2}{c}{$\begin{array}{c}\text { Think so/ } \\
\text { Not specified }\end{array}$} & Do not think so & Total \\
\hline \multirow{2}{*}{ Can use it } & Frequency & 284 & 149 & 433 \\
& $\%$ & 65.59 & 34.41 & 100.00 \\
\hline Cannot use it/ & Frequency & 309 & 240 & 549 \\
Have no idea & $\%$ & 56.28 & 43.72 & 100.00 \\
\hline \multirow{2}{*}{ Total } & Frequency & 593 & 389 & 982 \\
& $\%$ & 60.39 & 39.61 & 100.00 \\
\hline & & & significance probability & 0.003
\end{tabular}

The null hypothesis is rejected with $1 \%$ significance level. It can be said that those who answered that old buildings can be used think that they want to reside.

Null Hypothesis B-6) There is not so much difference whether "those who come frequently (every day) think that old buildings cannot be used" or not.

Summary table concerning Null Hypothesis B-6) is exhibited in Table 6. 
Table 6. Summary table for Null Hypothesis B-6)

Q3: How do you feel about the image of the surrounding area at this shopping street? : Lively

Q3: How do you feel about the image of the surrounding area at this shopping street? : Want to reside

\begin{tabular}{|c|c|c|c|c|}
\hline \multirow[b]{2}{*}{ Q3: Lively } & \multicolumn{3}{|c|}{ Q3: Want to reside } & \multirow[b]{2}{*}{ Total } \\
\hline & & $\begin{array}{c}\text { Think so/ } \\
\text { Not specified }\end{array}$ & Do not think so & \\
\hline \multirow{2}{*}{$\begin{array}{c}\text { Think so/ } \\
\text { Not specified }\end{array}$} & Frequency & 341 & 127 & 468 \\
\hline & $\%$ & 72.86 & 27.14 & 100.00 \\
\hline \multirow{2}{*}{ Do not think so } & Frequency & 252 & 262 & 514 \\
\hline & $\%$ & 49.03 & 50.97 & 100.00 \\
\hline \multirow{2}{*}{ Total } & Frequency & 593 & 389 & 982 \\
\hline & $\%$ & 60.39 & 39.61 & 100.00 \\
\hline
\end{tabular}

The null hypothesis is rejected with $1 \%$ significance level. It can be said that those who answered that the image of the street is lively think that they want to reside.

Null Hypothesis B-7) There is not so much difference whether "those who came from far away (Miscellaneous in Shizuoka Prefecture, Outside of Shizuoka Prefecture) think that they cannot judge whether old buildings can be used or not" or not.

Summary table concerning Null Hypothesis B-7) is exhibited in Table 7.

Table 7. Summary table for Null Hypothesis B-7)

Q9: Residence

Q4: There are many old building at the age of nearly 50 years. Do you think we can still use them?

\begin{tabular}{ccrrr}
\hline \multirow{2}{*}{ Q9 } & \multicolumn{2}{c}{ Q4 } \\
& & Cannot use it/ & \multicolumn{2}{c}{ Total } \\
\hline \multirow{2}{*}{ Neighborhood } & Frequency & 411 & 519 & 930 \\
& $\%$ & 44.19 & 55.81 & 100.00 \\
\hline \multirow{2}{*}{ Far away } & Frequency & 22 & 30 & 52 \\
& $\%$ & 42.31 & 57.69 & 100.00 \\
\hline \multirow{2}{*}{ Total } & Frequency & 433 & 549 & 982 \\
& $\%$ & 44.09 & 55.91 & 100.00 \\
\hline & & & significance probability & 0.790
\end{tabular}

The null hypothesis is not rejected. It can be said that there is not so much difference whether "those who came from far away (Miscellaneous in Shizuoka Prefecture, Outside of Shizuoka Prefecture) think that they cannot judge whether old buildings can be used or not" or not.

Null Hypothesis B-8) There is not so much difference whether "t hose who answered that the purpose of visiting the shopping street is eating and drinking are male in majority" or not.

Summary table concerning Null Hypothesis B-8) is exhibited in Table 8. 
Table 8. Summary table for Null Hypothesis B-8)

Q7: Sex

Q2: What is the purpose of visiting here? : Eating and drinking

\begin{tabular}{ccrrr}
\hline \multirow{2}{*}{ Q7 } & \multicolumn{4}{c}{ Q2: Eating and drinking } \\
& No & Yes & Total \\
\hline \multirow{2}{*}{ Male } & Frequency & 386 & 94 & 480 \\
& $\%$ & 80.42 & 19.58 & 100.00 \\
\hline \multirow{2}{*}{ Female } & Frequency & 445 & 57 & 502 \\
& $\%$ & 88.65 & 11.35 & 100.00 \\
\hline \multirow{2}{*}{ Total } & Frequency & 831 & 151 & 982 \\
& $\%$ & 84.62 & 15.38 & 100.00 \\
\hline & & & significance probability & 0.000
\end{tabular}

The null hypothesis is rejected with $1 \%$ significance level. It can be said that those who answered that the purpose of visiting the shopping street is eating and drinking are male in majority.

Null Hypothesis B-9) There is not so much difference whether "those who live in Fuji city have the purpose of eating and drinking while visiting the shopping street" or not.

Summary table concerning Null Hypothesis B-9) is exhibited in Table 9.

Table 9. Summary table for Null Hypothesis B-9)

Q9: Residence

Q2: What is the purpose of visiting here? : Eating and drinking

\begin{tabular}{ccrrr}
\hline \multirow{5}{*}{ Q9 } & \multicolumn{4}{c}{ Q2: Eating and drinking } \\
Fuji city & Frequency & 664 & Yes & Total \\
& $\%$ & 83.73 & 129 & 793 \\
& Frequency & 167 & 16.27 & 100.00 \\
\hline \multirow{2}{*}{ Else } & $\%$ & 88.36 & 11.64 & 189 \\
& Frequency & 831 & 151 & 100.00 \\
\hline \multirow{2}{*}{ Total } & $\%$ & 84.62 & 15.38 & 100.00 \\
& & & significance probability & 0.113
\end{tabular}

The null hypothesis is not rejected. It can be said that there is not so much difference whether "those who live in Fuji city have the purpose of eating and drinking while visiting the shopping street" or not.

\section{Remarks}

The Results for Hypothesis Testing are as follows. We set the following 7 themes.

A-1) Those who come frequently (every day) think that old buildings cannot be used.

A-2) Those who do not come so often (once a year) think that old buildings cannot be used.

A-3) Those who are at the age of less than 40 think that old buildings can be used.

A-4) Men think that old buildings cannot be used.

A-5) Those who answered that old buildings can be used think that they want to reside.

A-6) Those who answered that the image of the street is lively think that they want to reside.

A-7) Those who came from far away (Miscellaneous in Shizuoka Prefecture, Outside of Shizuoka Prefecture) think that they cannot judge whether old buildings can be used or not.

A-8) Those who answered that the purpose of visiting the shopping street is eating and drinking are male in majority.

A-9) Those who live in Fuji city have the purpose of eating and drinking while visiting the shopping street. 4 
cases out of 9 are rejected and nearly half of hypotheses (A-4, A-5, A-6, A-8) were insisted clearly.

\section{Conclusion}

Shopping streets at local city in Japan became old and are generally declining. In this paper, we handle the area rebirth and/or regional revitalization of shopping street. We focus on Fuji city in Japan. Four big festivals are held at Fuji city. Many people visit these festivals including residents in that area. Therefore a questionnaire investigation to the residents and visitors is conducted during these periods in order to clarify residents and visitors' needs for the shopping street and utilize them to the plan building of the area rebirth and/or regional revitalization of shopping street. Hypothesis testing was executed based on that.

In the hypothesis testing, 4 out of 9 null hypotheses were rejected and nearly half of hypotheses (A-4, A-5, A-6, A-8) were insisted clearly.

It was made clear that there are many people who want to reside near the vital shopping street. Men mainly visit the shopping street for the purpose of eating and drinking and think that old building can still use it. To make promotion to such people is a way to increase population.

There is a limitation in this research that the research period is restricted during the festival time. As for this, the questionnaire investigation should be executed in the plural years and should be analyzed. Further study on this will bring forth much more exquisite analysis.

These are utilized for constructing a much more effective and useful plan building.

Although it has a limitation that it is restricted in the number of research, we could obtain the fruitful results. To confirm the findings by utilizing the new consecutive visiting records would be the future works to be investigated.

\section{Acknowledgements}

The authors are grateful to all those who supported us for answering the questionnaire investigation.

\section{References}

Atami city. (2015). "2014 Survey of Tourist Behavior".

Doi, H. (2009). Evaluation of policies to build tourist destinations and statistical analysis. Nippon Hyoron Sha.

http://www.kawazu-onsen.com/eng/

https://www.jnto.go.jp/eng/location/rtg/pdf/pg-410.pdf\#search='Izupeninsula'

Ingu, S., Uemura, M., Uchida, Y., Omiya, M., Miura, T., \& Hironori, H. (2017).A study on the application of geothermal power generation to local revitalization in Obama Town, Unzen City: in consideration of futurability in Obama. Environmental Science Research, Nagasaki University, 20(1), 51-63.

Inoue, A. (2017). .Changes in Local Communities Brought by Municipal Mergers : From the Viewpoint of Tourism Promotion as the Main Industry. Bulletin of the Faculty of Regional Development Studies, Otemon Gakuin University, 2, 1-32.

Japan Tourism Agency. (2015). "Research study on economic impacts of tourism in Japan 2013, p3.

Kano, M. (2011). Characteristic analysis of Atami tourists: Reconsideration based on data add and modify. Shizuoka Economic Research, 16(2), 61-78, Shizuoka University

Kotani, A. (2017). The implementation report of the Machi-lab shutter art project. Bulletin of Wakkanai Hokusei Gakuen University, 17, 207-218.

Ohkubo, Y. (2017). Current status and problems in Jigenji-dori shopping area : from a consumer questionnaire. Bulletin of Local Research, Kagoshima International University, 44(2), 1-15.

Shioya, H. (2009). Overview and application of tourism statistics: Analysis using statistical survey on overnight travels. Journal of Economic Structures, 17(1-2), 16-29. Pan Pacific Association of Input-Output Studies. https://doi.org/10.11107/papaios.17.1-2_16

Takeyasu, K. et al. (2010). "Modern Marketing”, Chuoukeizaisha Publishing.

Yoshida, I. (2009). Consideration on the Characteristic of Visitors' Activity and the Research Method for Tourist Visitors in Urban Areas. 


\section{Appendix}

\section{Questionnaire Sheet about the Image Around the Shopping Street}

1. How often do you come to this shopping street?
a. Everyday
b. ( ) times a week
c. ( ) times a month
d. ( ) times a year
e. miscellaneous
( )

2. What is the purpose of visiting here? (Plural answers allowed)
a. shopping $b$. eating and drinking
c. business
d. celebration, event
e. leisure, amusement $\mathrm{f}$. miscellaneous ( )

3. How do you feel about the image of the surrounding area at this shopping street? Select the position.

\begin{tabular}{|c|c|c|c|c|c|c|}
\hline Beautiful & $\cdot$ & $\cdot$ & $\cdot$ & • & • & Ugly \\
\hline Of the united feeling there is & $\cdot$ & $\cdot$ & $\cdot$ & $\cdot$ & $\cdot$ & Scattered \\
\hline Varied & $\cdot$ & $\cdot$ & $\cdot$ & $\cdot$ & $\cdot$ & Featureless \\
\hline New & $\cdot$ & $\cdot$ & $\cdot$ & $\cdot$ & $\cdot$ & Historic \\
\hline Full of nature & $\cdot$ & $\cdot$ & $\cdot$ & $\cdot$ & $\cdot$ & Urban \\
\hline Cheerful & • & $\cdot$ & $\cdot$ & $\cdot$ & $\cdot$ & Gloomy \\
\hline Individualistic & $\cdot$ & $\cdot$ & $\cdot$ & $\cdot$ & $\cdot$ & Conventional \\
\hline Friendly & • & • & $\cdot$ & . & • & Unfriendly \\
\hline Healed & $\cdot$ & $\cdot$ & $\cdot$ & $\cdot$ & $\cdot$ & Stimulated \\
\hline Open & • & • & • & • & • & exclusive \\
\hline Want to reside & $\cdot$ & $\cdot$ & $\cdot$ & $\cdot$ & $\cdot$ & Do not want to reside \\
\hline Warm & - & • & $\cdot$ & $\cdot$ & $\cdot$ & Aloof \\
\hline Fascinating & $\cdot$ & $\cdot$ & $\cdot$ & $\cdot$ & $\cdot$ & Not fascinating \\
\hline Want to play & • & • & $\cdot$ & • & $\cdot$ & Want to examine deliberately \\
\hline Lively & $\cdot$ & $\cdot$ & $\cdot$ & $\cdot$ & $\cdot$ & Calm \\
\hline Atmosphere of urban & $\cdot$ & • & $\cdot$ & $\cdot$ & $\cdot$ & Atmosphere of rural area \\
\hline
\end{tabular}

4. There are many old building at the age of nearly 50 years. Do you think we can still use them?
a. Can use it
b. Cannot use it
C. Have no idea

5. Is there any functions or facilities that will be useful?

\section{Comments}

\section{Sex
a. Male
b. Female

8. Age
a.10th b.20th
c.30th
d.40th e.50th
f.6th
g. More than 70

9. Residence

a. Fuji City b. Fujinomiya City c. Numazu City d. Mishima City e. Shizuoka City f. Miscellaneous in Shizuoka Prefecture g. Outside of Shizuoka Prefecture [

\section{Copyrights}

Copyright for this article is retained by the author(s), with first publication rights granted to the journal.

This is an open-access article distributed under the terms and conditions of the Creative Commons Attribution license (http://creativecommons.org/licenses/by/4.0/). 